\title{
Potential Contribution of Solar Drying Systems to Development of Rural Communities: A Case Study in Thailand
}

\author{
Yue MorIIzUmi ${ }^{\dagger}{ }^{\dagger}$, Hiroki HONDO ${ }^{* 1}$, and Piyawan SRI-AMPAI ${ }^{2}$ \\ (Received March 31, 2020)
}

\begin{abstract}
農村コミュニティの発展における太陽熱乾燥システムの貢献可能性 : タイにおけるケースタディ 森泉由恵*1†，本藤祐樹*1，スリアンパイ・ピヤワン*2
\end{abstract}

The purpose of this study is to examine whether the introduction of solar drying systems contribute to the development of rural community activities in Thailand. In this study, interviews are conducted with six farmer groups who use solar drying systems for their production activities, and the empirical findings from the interviews are used as data for the analysis. The case analysis reveals that the introduction of solar drying systems has the potential to create the following three values. First, its introduction has the potential to motivate community members and bring out their initiative through the improvement of the working environment. The second is the possibility that its introduction may naturally induce learning to improve members' competence, triggered by a change in drying methods. Third, its introduction has the potential to enhance the sustainability of local communities by strengthening ties within local communities and ensuring succession. More importantly, the use of renewable solar thermal energy realizes the three values mentioned above without the consumption of fossil fuels. This study suggests that the installation of solar drying systems may not only contribute to global environmental sustainability in terms of climate change mitigation, but also to the sustainable development of rural communities in developing countries.

\section{Key Words}

Renewable energy, Solar thermal energy, Community enterprise, Learning, Sharing, Motivation,

Local sustainability

本研究の目的は, 太陽熱乾燥システムの導入がタイの農村コミュニテイ活動の発展に貢献するか否かを検討することであ る。本研究では, 太陽熱乾燥システムを生産活動に利用している6つの農民グループに対してインタビュー調査を行い, そ

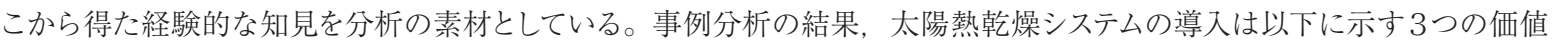
をもたらす可能性が見出されている。第一に，軽労化という労働環境の改善を通して，コミュニティメンバーのモチベーショ ンを高め, 主体性を引き出す可能性である。第二に, 導入による乾燥方法の変化をきっかけとして, メンバーの能力向上の ための学習が自然に誘発される可能性である。第三に, 農村コミュニティ内のつながりの強化と後継者の確保をもたらし, 地域社会の持続性を向上させる可能性である。さらに重要な点は, 再生可能な太陽熱エネルギーを利用することで, 化石 燃料の消費を伴うことなく，上述の3つの価值を実現することにある。本研究の結果は，太陽熱乾燥システムの導入が，気 候変動の緩和という地球環境の持続性に資するだけでなく, 途上国における農村コミュニティの持続的な発展に資する可能 性を示唆している。

$$
\text { キーワード }
$$

再生可能エネルギー, 太陽熱エネルギー, コミュニティ・エンタープライズ, 学習, 共有, モチベーション, 地域の持続性

\footnotetext{
※1 Graduate School of Environment and Information Sciences, Yokohama National University

79-7 Tokiwadai, Hodogaya-ku, Yokohama 240-8501, Japan

※ 2 Faculty of Economics, Chulalongkorn University

254 Phyathai Road, Patumwan, Bangkok 10330, Thailand

$\uparrow$ Corresponding author: yue-m@ynu.ac.jp
}

\author{
$※ 1$ 横浜国立大学大学院環境情報研究院 \\ $\overline{\mathbf{T}} 240-8501$ 横浜市保土ケ谷区常盤台 79-7 \\ ※2 チュラロンコーン大学経済学部 \\ Phyathai Road, Patumwan, Bangkok 10330, Thailand
}




\section{1. はじめに}

近年, 再生可能エネルギーと農村地域の発展の関係をめ ぐる議論が活発に行われている。農村地域の多くは，人口 減少や高齢化による地域の衰退, 都市部との所得格差など 様々な課題を抱えている。再生可能エネルギーの導入は, 雇 用や所得の創出, 農村経済の多角化, 生活条件・環境の改 善などの面で農村地域の発展に貢献する可能性がある ${ }^{1) ~ 3) 。 ~}$ さらに，地域資源に立脚したコミュニテイ主導型の発展が指 向される世界的潮流のなか, 再生可能エネルギーを導入・利 用する過程でコミュニティの能力が向上し, 主体性が醇成さ れることが期待されている ${ }^{4)}$ 5)。これまでに，地域での雇用 創出や収入の増加, 地域経済の多角化, 地域社会の結束の 強化といった観点から再生可能エネルギーの影響評価が行

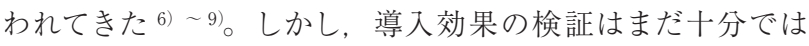
ないことが指摘されている10)11\%

また，既往研究が対象とする再生可能エネルギー技術は， 太陽光発電, 風力発電, バイオマス発電が大勢を占めており, 太陽熱による乾燥など直接熱利用技術を対象とした分析は 少ない。太陽熱乾燥技術は，システムが簡易で比較的安価 であるため，途上国の農村部においても導入しやすいという 利点がある。特に, 食品乾燥は, 収穫後の農産物の長期保 存を可能にし, 付加価值を向上させる重要な技術である。最 も伝統的な乾燥技術は天日干しであるが，天候に左右され やすく，ゴミや埃による品質劣化，昆虫や家畜などの動物に よる食害や衛生被害といった欠点がある。また，天日干しは 水分量のコントロールが難しく, 品質が安定しない。そこで, 途上国の農村部での利用を想定して，太陽熱を用いた乾燥 技術の開発が精力的に行われてきた ${ }^{12) ~}$ 14)。

タイ政府は, 現在, 太陽熱乾燥システムの普及政策を推進し ている。エネルギー省代替エネルギー開発・エネルギー保全局 (以下, DEDE: Department of Alternative Energy Development and Efficiency) は, 2011 年から「パラボラドーム」と呼ばれ る太陽熱乾燥システムの導入プロジェクトを開始した。パラ ボラドーム導入の目的は，第一に，乾燥機の利用に伴う化石 燃料消費量の削減, 第二に, 乾燥品の衛生面での付加価值 向上である。乾燥食品製造は, 夕イ経済に扮ける重要な産 業である。パラボラドームは, 果実類, スパイス・ハーブ類, 野菜類, 魚介類など幅広い農水産物の乾燥に用いられ, 北部· 東北部から南部まで夕イ全土で導入されている。2018 年まで の設置数は 421 ヶ所 $\left(49,757 \mathrm{~m}^{2}, 134,403 \mathrm{GJ} /\right.$ 年に相当) に のぼる ${ }^{15)}$ 。2015 年に発表された代替エネルギー開発計画で は，2036 年までに 750 ヶ所にパラボラドームを導入すること を目標として揭げている ${ }^{16)}$

パラボラドーム導入の対象は, 個人農家，農民グループ, 中小企業であるが，特に農民グループへの普及が重視されて いる。夕イ政府は農業戦略において, 農民の組織化と能力 向上を, 農業部門の国際競争力強化, 持続的農業の推進と 並ぶ目標に位置付けている ${ }^{17)}$ 。農民の組織化と能力向上は, ラーマ9世 (プミポン前国王) が提唱した足るを知る経済理 念脚注1) で示される農村発展モデルにおける鍵である。組織
化により小規模農家の立場の弱さを解消し，その活動を通し て農産物高付加価值化のための知識や技術を身につけ，農 家の自立および生活の質の向上を実現することが目指されて いる。パラボラドームの導入は，こうした農民グループの活 動を後押しするものとして期待されている。

農民の組織化を推進する政策として，農業・協同組合 省農業普及局（以下，DOAE: Department of Agricultural Extension）が推進するコミュニティ・エンタープライズ政策 があげられる。コミュニティ・エンタープライズとは，農産品 の販売や加工など, 何らかのビジネスを協働で行うことを目 的に 7 人以上のメンバーが集まり, 正式に登録を行ったグルー プを指す 19)。2018 年時点で, 70,000 以上のグループがコミュ ニティ・エンタープライズとして認可されている。しかしなが ら, 商品開発や販路開拓など経営面での課題, リーダーシッ プの欠如やメンバー間のトラブルなど組織運営面での課題を 抱えるケースが多く，活動が軌道に乗っているグループは多 いとは言えない20)～22)。そのため，コミュニティ・エンタープ ライズの維持・発展のための方策が模索されている。

こうした背景から, 本研究は, 再生可能エネルギー技術と して太陽熱乾燥システムを取り上げ，農村地域発展の土台と なるコミュニティ経済活動の維持・発展に貢献する可能性を 検討する。具体的には, パラボラドームを導入したコミュニ ティ・エンタープライズを対象とし，導入により生じた変化を 把握, 分析する。

\section{2. 分析の対象}

本章では, 本研究が対象とする太陽熱乾燥システムとコ ミュニティ経済活動について述べる。同時に，既往研究の 概観を通して本研究の位置づけを明確にする。なお，以下 のタイの施策に関する説明は，パラボラドーム普及政策を 担当する DEDE，パラボラドームの開発を行っているシリパ コーン大学，コミュニティ・エンタープライズ政策を担当す るDOAE，ならびに，土地を所有しない農民への土地の利 用権付与等を担当する農業・協同組合省農地改革局 (以下, ALRO: Agricultural Land Reform Office）に対するヒアリング で得た情報に基づく。

\section{1 太陽熱乾燥システム}

\subsection{1 パラボラドームの概要}

パラボラドームは，シリパコーン大学が開発した空気循環 式の太陽熱乾燥システムである (Fig. 1)。形状は日本のビ ニールハウスと類似している。効率的かつ均一な乾燥を行う 構造となっており, 内部の温度は晴天の場合には $60^{\circ} \mathrm{C}$ 程度 に上昇する。建築方法は，まず，敷地全面にコンクリート基 礎を施す。基礎の表面は, 熱を吸収して内部の温度を上昇 させるため, 黒色顔料を練り混ぜたコンクリートでコーティン

脚注 1)「足るを知る」経済理念は，「安定的で調和の取れた 持続可能な進歩」を実現するための国の指針である。 SDGs の 17 の目標に関しても，この理念を適用すること で達成を目指している18)。 


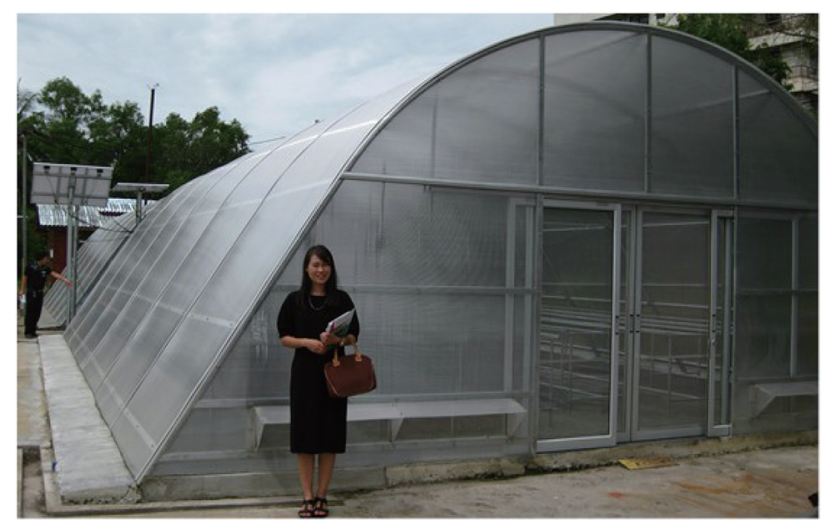

Fig. 1 Parabola dome in Thailand

グする。食品衛生上, 塗料の表面塗布による着色が許可さ れないためにこの方法を用いている。次に，パイプで骨組み を作り, 外壁を厚さ $6 \mathrm{~mm}$ のポリカーボネートシートで被覆 する。最後に, 温度・湿度調整用のファン, 乾燥用の台, 雨 に備えた補助熱源としての LPG バーナー, ファン動力源とし ての太陽光発電設備, 出入口の扉を設置する。建設には 10 日程度を要する。DEDEでは普及政策の一環として, 建設業 者へのパラボラドーム建設研修を実施している。建設後は, 台風による破損や倒壊がなければ, 10 年程度使用すること ができる。定期点検やメンテナンスは必要ないとされている が, ファンの故障や乾燥用の網の劣化が起きた場合は修理・ 交換が必要になる。また, コンクリート基礎の黒色が薄くなっ た場合は，再度，コーティングを行う必要がある。

サイズは大・中・小の 3 種あり, 床面積はそれぞれ $8.0 \mathrm{~m}$ $\times 20.8 \mathrm{~m}, 8.0 \mathrm{~m} \times 12.4 \mathrm{~m}, 6.0 \mathrm{~m} \times 8.2 \mathrm{~m}$, 価格は 88 万 Baht, 58 万 Baht, 28 万 Bahtである。導入政策が開始され た 2011 年には，DEDEが初期投資の $60 \%$ を補助している。 2012 年以降, 補助金は 1 年ごとに $5 \%$ ずつ少なくなり, 2017 年は 35\%補助となっている。2018 年以降は, 30\%補助で固 定される予定である。ただし，対象がコミュニティ・エンター プライズである場合や，小サイズの導入の場合は，DEDEが 全額補助することもある。また，パラボラドームは，インド やカンボジア，ベトナムなどタイ以外の国でも設置されている ほか，セネガルに対する技術供与も実施されている。

\section{1 .2 太陽熱乾燥システムに関する既往研究}

太陽熱乾燥システムを対象とした既往研究は，技術開発 およびその性能評価をテーマとする研究が中心である。乾燥 速度や効率，乾燥温度などを指標として開発したシステムの 性能を検証する研究, 最適な設計の検討を行う研究が数多 く実施されている23) 27)。

システムの性能評価以外の研究では, 導入の意思決定に おいて重要な要素である経済性の観点, および, 乾燥後の 製品品質の観点からの評価が行われている。経済性評価で は, 投資回収期間を算出している研究が多く, 例えば, イン ドに打けるキャビネット型のシステムでは 3.26 年 ${ }^{28)}$, タイにお ける貯湯タンクと熱交換機を備えたシステムでは 1.37 年 ${ }^{29}$, タイに㧍ける集熱パネル屋根設置システムでは 5 年 ${ }^{30)}$, チュ
ニジアにおけるグリーンハウス型システムでは 1.6 年 ${ }^{31)}$ といっ た結果が得られている。

製品の品質評価では，Hossain and Bala ${ }^{32)}$ が，バングラ デイシュにおけるトンネル式太陽熱乾燥システムの性能評価 と, 乾燥後の唐辛子の外観と食味に関する品質評価を行っ ている。本研究が対象とするタイのパラボラドームに関して も, システムの性能評価, 経済性評価とともに, 外観, 香り, 食味，食感といった製品品質の評価が行われている33３4）

また，数は多くないものの, $\mathrm{CO}_{2}$ 排出量など環境負荷に着 目した研究も実施されている。実測およびシミュレーション モデルにより，化石燃料や電気を太陽熱で代替した場合の $\mathrm{CO}_{2}$ 削減ポテンシャルの評価が行われている35) 38)。

以上のように, 先行研究では太陽熱乾燥システムの導入 効果として, 経済性や製品品質の改善, 環境負荷の軽減が 考えられている。しかし, 新技術が生産活動に導入された時 の影響は, 個人や組織の行動変化など, さらに広範な観点 から検討する必要がある。

\section{2 コミュニティ経済活動}

\subsection{1 コミュニティ・エンタープライズの概要}

タイ政府は，2005 年にコミュニティ・エンタープライズ法 を成立させた。農民組織化政策は古くから実施されていた が，この法律により，組織が法人格を持たなくても法律上の 正式なステータスが保証され, 政府機関の各種資金やサポー トにアクセスできる権利が与えられた。政策の中心を担う政 府機関はDOAEであるが, ALROにより新たに土地を付与 された農家が, New theory㬨注2)などの持続的農業を実践し， そこからコミュニティ経済活動につながるケースも多いため, ALRO も梁く政策に関与している。事業の内容は 7 割が農業 関連であり, 野菜, 果物, コメの販売業, 畜産業, 食品加 工業などである。残りの 3 割は OTOP プロジェクト朋注3)によ る製品であることが多いため，支援には内務省コミユニティ 開発局が関わっている。

コミュニティ・エンタープライズとして正式に認可されるた めには, 登録を行う必要がある。登録は，世帯が異なるメ ンバーが7人以上集まること, ビジネスプランが策定されて いることという条件を満たせば良い。登録手続きは簡易であ り, グループの名称・所在, メンバーの氏名・住所のリスト, サイン付き認可書等を郡の DOAE に提出する。申請書類の 提出時に, グループの能力判定のためのチェックシートの記 入を行う。申請後, チェックシートに基づいてグループのポ テンシャル評価が行われ, 開発プランが作成される。登録 後は，その開発プランに基づき各種の研修や指導，支援が 実施されるとともに, タンボン䀧注 4 () の DOAE スタッフによる 活動状況のチェックが行われる。

脚注 2) New theory とは, 複合農業の一形態であり,「足るを 知る」経済理念に基づく。

脚注 3) OTOP (One Tambon One Product) プロジェクトとは, 日本の一村一品運動をモデルとした住民自身の力による 地域づくりを目的としたプロジェクトを指す。

脚注 4) タンボン (Tambon) は, いくつかの村をまとめた行政単 位であり, 郡 (Amphoe) の下位, 村 (Muban) の上位に あたる。 
コミュニティ・エンタープライズの活動は，当事者意識を 持った主体的な取り組みであること，地域資源と地域の伝 統知を活用すること, 可能な限りコストを抑えること, 適正 な規模であることが望ましいとされる。また，「発展すなわ ち学習」との理念の下, 自分達自身の強みや弱みを知り, 知 識を共有し, 外部からも積極的に学ぶことが推奨される。さ らに，事業で得た利益の公平な分配と利用および貯蓄を促 すため,「Welfare fund」と呼ばれる共通基金を創設するこ とが推奨されている。

\subsection{2 コミュニティ・エンタープライズに関する既往研究}

コミュニティ・エンタープライズに関する既往研究の重点は, 活動のパフォーマンスに影響を与えるキーファクターを明らか にすることに置かれている。分析手法は，「成功しているグ ループ」と「成功していないグループ」との比較を行い, そ の相違点から成功要因を推察するものである。

例えば, Ruengde and Wongsurawat ${ }^{39)}$ はモチベーションと 経営能力に着目し，ペチャブリ県のコミュニティ・エンタープ ライズを対象に質問紙調査とインタビュー調査を行っている。 その結果から，コミュニテイ活動の成功には，メンバーの内 発的モチベーションが高く活動に対する主体性があること, コミュニケーションが活発で系統立った分業体制が構築され ていること, 活動の収支を把握·記録していること, マーケティ ング戦略を策定していることが必要であると結論づけてい る。Sutthsakorn ${ }^{40)}$ は，ナレッジマネジメントと学習プロセス に着目し， ウボンラチャタニ県のコミュニティ・エンタープラ イズを対象にインタビュー調査を行った。その結果から, 組 織の立ち上げ期においては，グループリーダーの経験学習と 暗黙知が重要であること, 活動の拡大期においては, 研修 や視察・消費者への調査などから得た知識を生産に活用す る実践による学習が重要であると結論づけている。同様に, リーダーシップ，メンバー間の信頼関係，政府機関との関係 性の強さが成功要因であるとする研究 ${ }^{41)}$, メンバー間での目 標の共有, ベネフィットの公平な分配, リーダーシップ, 組 織内コミュニケーションが成功要因であるとする研究 ${ }^{42}$, 人 的資本が成功を決める要素であるとする研究 ${ }^{43)}$ があげられ る。

このように, 先行研究では, コミュニテイ活動の成功の主 要因として, 人的資本と組織資本に関する要素が多くあげら れているが，統一した結論は得られていない。また，先行 研究ではもっぱら人的・組織資本など経営資源の内容に焦 点が当てられており，これらの経営資源がどのように活動の 成功に結び付くかというプロセスには関心が寄せられていな い。これまでに，パラボラドーム導入を含めコミュニテイ活 動の支援策の効果・影響に着目した分析は行われていない が，支援策がもたらす変化は多様であることが予想される。 そのため，分析では，経営資源のみならず，事業全体を包 括的に捉える必要がある。

\section{3. 分析方法と調査対象}

\section{1 分析のフレームワークと調査項目}

パラボラドームの導入による影響を把握するため, コミュ ニティ・エンタープライズのメンバーに対するインタビュー調 査を実施した。インタビュー調査は，企業の業績評価や経 営管理のためのフレームワークである Brown ${ }^{44)}$ のモデルに 基づいて行った。Brownのモデルはロジックモデルをべース とするものであり, 企業が所有する様々な経営資源からス夕ー トし (インプット)，それらを変換する過程を経て (ビジネス プロセス)，財・サービスが生産され (アウトプット), 財・サー ビスを提供することで価值を生み出すとともに（アウトカム）, 活動を通して組織の目標を達成する（ゴール）という一連の 流れで企業の活動を表現している。このモデルにより, 経営 資源が最終的な目標に結びつくプロセスを明示することがで きる。インタビュー調査では，パラボラドームの導入目的に 関する変化，ならび，上記の5つの段階に打ける変化につい て質問した。8つの質問項目を以下に示す。

(1) 化石燃料使用量の変化 (導入目的)

(2) 衛生面に打ける品質の変化 (導入目的)

（3）メンバーに関する変化（インプット）

組織を構成するメンバーの意識や態度，スキルなど，人 的資本に関する変化を問うものである。

(4)組織に関する変化 (インプット) メンバー間の信頼関係や協力関係の高まりなど，組織資 本に関する変化を問うものである。

(5)経営資源の変換過程に関する変化 (ビジネスプロセス) 生産の効率化やコスト削減など，事業の方法に関する変 化を問うものである。

（6）生産物に関する変化（アウトプット）

衛生面以外の製品品質向上や新製品の開発など, 生産 物に関する変化を問うものである。

（7）事業の成果に関する変化 (アウトカム)

新規市場の開拓や顧客満足度の向上など，事業の成果 に関する変化を問うものである。

(8) 活動の最終的な目標に関する変化 (ゴール)

自立や生活の質向上など，組織の最終的な目標に関する 変化を問うものである。

これら 8つの項目に対し, パラボラドームの導入後における 変化の有無について，また変化があった場合にはその内容に ついて質問を行った。

\section{2 調査対象}

パラボラドームを生産活動に利用している6つの農民グ ループに対して，インタビュー調査を行った。6つのグルー プは, 全てコミュニティ・エンタープライズとして登録している。 調査は, 2018 年 6 月と 2019 年 12 月の 2 回にわけて実施し た。以下では，インタビューで得られた情報を元に，グルー プの活動内容や特徵, パラボラドーム導入の経緯等について 述べる。Table 1 に各事例の概要を, Fig. 2 に各事例の所在 地を示す。 
Table 1 Overview of six farmer groups

\begin{tabular}{lcccccc}
\hline & Case A & Case B & Case C & Case D & Case E & Case F \\
\hline Location (Province) & Khon Kaen & Khon Kaen & Sukhothai & Phitsanulok & Nakhon Pathom & Samut Songkhram \\
Founded & 2013 & 2011 & 1996 & 2000 & 2002 & 2003 \\
No. of members & 30 & 32 & 11 & 30 & 165 & 30 \\
Main Product & Reed basket & Mushroom & Dried banana & Dried banana & Dried tomatoes & Face powder \\
Annual sales & 150 & 90 & 370 & 3,000 & $4,000-8,000$ & 1,300 \\
(thou. Baht) & & & & & & \\
\hline
\end{tabular}

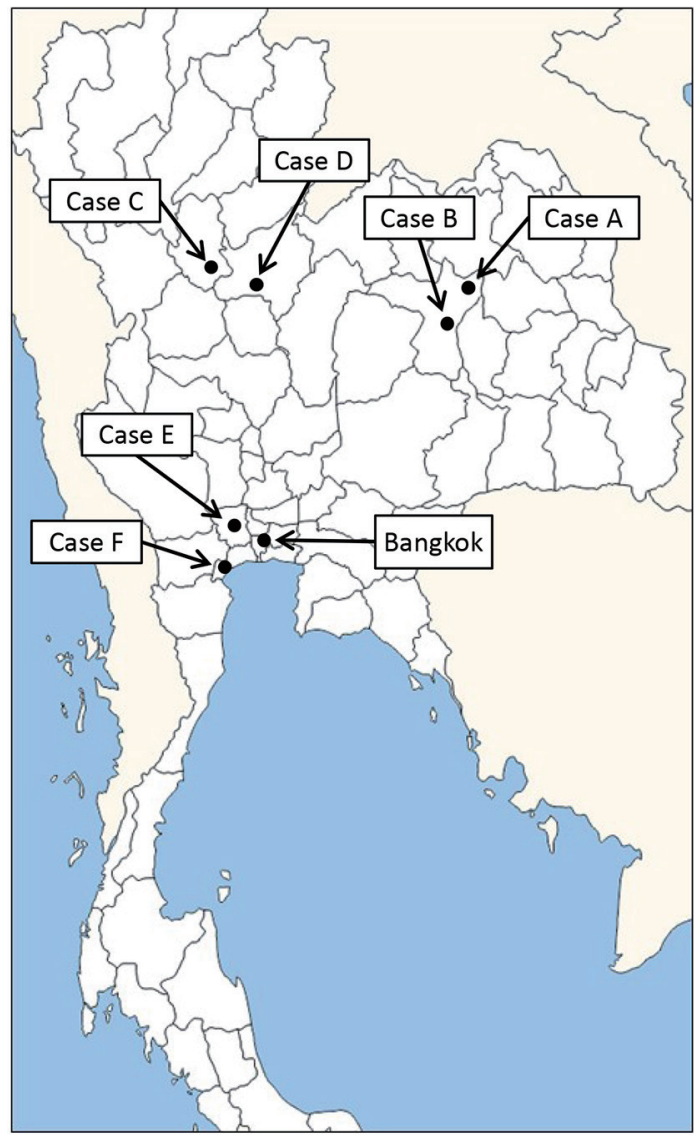

Fig. 2 Location of the study areas in Thailand

\subsection{1 事例 $A$}

事例 $\mathrm{A}$ は, 莘の栽培, および, 蔁によるバスケット等の生産. 販売を行うグループである。葦の栽培期間は 5 ケ月で一年中 収穫できるため, 活動も通年行っている。古くからコミュニ テイで手編みの莘マットを作成していたが, Khon Kaen 大学 からマットよりも加工度の高い製品の生産を勧められたこと をきっかけに，バスケット等の生産を始めた。コミュニティ・ エンタープライズの登録は 2013 年, メンバーは 30 人である。

製品の販売は, 政府から OTOP 展示会への出品を勧めら れて以降，本格化させた。販売店舗はなく，オンラインで注 文を受けて製品を郵送する。既に知名度が高いため多くの 注文があり，現在のところ販売に関する問題はない。年間売 上高は 15 万 Baht である。莘製品を生産するグループは多 数あるが, バスケット等の中にパーカオマーと呼ばれる夕イ
の伝統的なチェック柄の布を敷くこと, 蔁の染色にクミンや ジャックフルーツの種子など植物素材を用いることで差別化 を図っている。

製品の製造方法は, まず, 1 本の莘を細く割き, 乾燥させる。 十分に乾燥させた後, 染色を行い, 再度, 乾燥させる。そ れを用いてマットを編み，そこからバスケット等に加工する。 乾燥は天日干しで行っていたが, 2017 年にDEDEの勧めに よりパラボラドームを導入した。費用は全額 DEDE が負担し ている。

\subsection{2 事例 B}

事例 B は, キノコの共同栽培, および, キノコペーストを 原料とするキノコクラッカーの生産・販売を行うグループで ある。DOAE 職員の勧めにより，2011 年にコミュニティ・エ ンタープライズとして登録した。登録前は栽培したキノコをそ のまま販売していたが, 生産規模の拡大と一年を通して安定 した販売を行うことを目的として, キノコ加工品の生産に着 手した。メンバーは 32 人である。タンボンや郡の小売店や 病院に販売するほか, 直接注文を受けている。年間売上高 は 9 万 Bahtである。

製品の製造方法は，まず，キノコペーストを作り，夕ピ オカ粉と混ぜて生地とする。次に生地を棒状に成形し, 蒸 し, 冷却する。硬化した生地をクラッカー状に切断し, 乾燥 させる。乾燥後, 油で揚げて完成する。パラボラドームは, 2015 年にDEDEの勧めにより導入した。導入前は, 天日干 しを行っていた。最大サイズのパラボラドームを導入したた め, DEDEによる補助は初期投資額の $1 / 2$ である。残りの $1 / 2$ はグループリーダーである村長が全額負担したが, クラッ カーの販売利益から返済し， 2 年間で完済している。

\subsection{3 事例 C}

事例 C は, バナナ栽培, および, ドライバナナの生産· 販売を行うグループである。グループ結成は 1996 年で, 現 在のメンバー数は 11 人である。活動開始当初はバナナチッ プを生産していたが，生産者数が多く競争が激しいためドラ イバナナの生産に変更した。以前は生産が追い付かないほ ど需要が高く, バンコクの店舗にも出荷するほど人気があっ たが，1〜2年前から需要が激減した。大雨や洪水の影響 でバナナが不作だったこともあり, 年間生産量を以前の $24 \mathrm{t}$ から $2.4 \mathrm{t}$ 程度に縮小している。Facebookで宣伝を行うなど 新たな試みも行っているが, 近隣住民が購入する程度でそれ 以上の広がりはなく, マーケティングに苦慮している。現在 


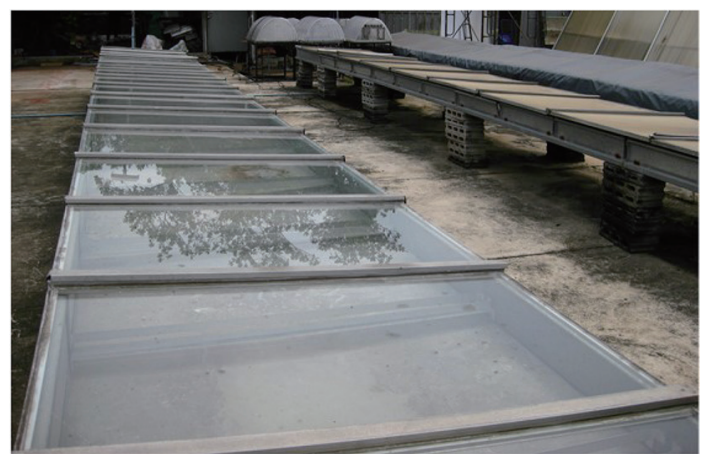

Fig. 3 Cabinet type solar dryer

の年間売上高は 37 万 Baht である。

パラボラドーム導入前はキャビネット型太陽熱乾燥機を用 いていた（Fig. 3）。キャビネット型太陽熱乾燥機は，本体は スチール製で上部はガラスでカバーされている。側面には, 乾燥用トレーを出し入れする口が備えられている。以前の乾 燥機は雨などによる劣化が激しかったため, シリパコーン大 学に勧められたのをきっかけに，2012 年にパラボラドームを 導入した。初期投資のうち, 基礎工事費は自己負担であり, 材料費・建設費は DEDEが負担している。

\subsection{4 事例 D}

事例 D は，事例 C と同じくドライバナナの生産・販売を 行うグループである。活動開始は 2000 年でメンバー数は 30 人である。グループ結成以前はメンバーが個々にドライバナ ナを生産していたが, バーゲニングパワーを得るために共同 生産を開始した。現在は, バナナの栽培・購入, 加工, 乾 燥をメンバーが単独で行い, 完成したドライバナナをリーダー が買い取ってパッケージングした上で販売している。販売先 は， 8 割が郡の土産店，2 割がバンコクの仲買人である。 王室に贈呈する地域の名産品に選ばれるなど高い評価を受 けている。年間生産量は $36 \mathrm{t}, \quad$ 年間売上高は 300 万 Baht である。

パラボラドーム導入前はキャビネット型太陽熱乾燥機を用 いていたが, 効率や使い勝手が悪かったため, リーダーが DOAE に改善の要望を提出した。数年後にDEDE とシリパ コーン大学から連絡があり, パラボラドーム導入に至った。 2012 年に 1 基目を導入し, 現在では 30 人のメンバーのうち 15 人がパラボラドームを所有している。初期投資は， 1 基目 はDEDEによる全額補助，2基目以降は，DEDEが 6 割， グループが 4 割を負担している。

\section{2 .5 事例 $E$}

事例 $\mathrm{E}$ は, チェリートマト栽培, および, ドライトマトの生産. 販売を行うグループである。活動開始は 2002 年である。グ ループ結成時のメンバー数は 7 人だったが, 現在では 165 人 に増えている。ドライトマトの製造・販売を行うのは 1 月から 4月のみである。以前は一年を通して生のチェリートマトを販 売していたが，出荷最盛期である1月から 4 月は価格が大幅 に下落するため, 年間 $100 〜 200$ tのトマトを廃棄していた。 そこで, トマトの加工を開始した。販売はオンラインで行っ
ている。年間売上高は 400 万〜 800 万 Bahtである。ドライ トマトの生産は, 選別・洗浄·搾汁・シロップ漬け・乾燥・パッ ケージングと多くの人手を必要とするため, メンバー以外の日 雇い労㗢者を雇用している。

パラボラドームは, シリパコーン大学の勧めにより 2012 年に導入した。現在は, DEDEが海外の政府や企業にパ ラボラドームを紹介する際の視察先となっている。導入前 は, LPG 乾燥機を使用していたが, 徐々にメンバー数が増 えて生産規模が拡大したため, LPG 乾燥機では対応できな くなった。導入費用は DEDEによる全額補助である。ドラ イトマトの製造はリーダー宅にある1ヶ所の加工場で行ってお り, 乾燥もパラボラドーム 1 基で行っている。収穫後のトマト を加工場まで輸送できないメンバーに対しては, リーダーが $1 \mathrm{Baht} / \mathrm{kg}$ で輸送を代行する。

\subsection{6 事例 F}

事例 F は，海塩を原料とするフェイスパウダーの生産・販 売を行うグループである。1997 年に事業を始めた当初はリー ダーが1人で地域の伝統品であるルースパウダーを製造して いたが，注文の増加を契機として 2003 年にコミュニティ・エ ンタープライズを設立した。ただし，利益の分配を巡るトラ ブルを避けるため, 経営は全てリーダーが行い, メンバーに は仕事に応じた賃金を払う形式を取っている。現在は，この 地域がバンコクに近い観光地であることを利用し，主力製品 であるフェイスパウダーを用いたフェイスパックとフェイスパウ ダーづくりの体験教室をセットにした日帰り旅行プランを提 供している。フェイスパウダーの年間売上高は 130 万 Baht である。輸出も視野に入れているが，製造をすべて手作業 で行っているため衛生面での課題が多く, 保健省食品医薬 品局の認証, および, GMP 㑢注5)の適合証明書の取得には至っ ていない。

フェイスパウダーの製造方法は, まず, 原料の海塩を洗浄 し，粒の大きさにより 3 種に分別する。次に，分別した原料 を煎って水分を飛ばす。粉状になった原料を水に溶かし, 滤 過する。それを底面の直径が $1 \mathrm{~cm}$ 程度の円錐状に成形し, 乾燥させる。完全に乾燥した固形状のパウダーを作った後, それをすり潰して粉状にしている。パラボラドーム導入以前 は天日干しを行っていたが, 天候や衛生面での問題が大き かったためリーダーが DEDE に相談した。それがきっかけと なり， 2013 年にパラボラドームを導入した。費用は DEDEに よる全額補助である。

\subsection{7 事例の特徵と共通点}

事例 $\mathrm{A} \cdot \mathrm{B}$ は, 「足るを知る」経済理念にしたがいモノカ ルチャーから複合農業に転換した農家による組織であり,グ ループでの協働や結束を重視していることが特徴である。事 例 $\mathrm{E} \cdot \mathrm{F}$ は, リーダーの経営者能力が高く, ビジネスの成功 を重視している点が特徵である。事例 $\mathrm{C} \cdot \mathrm{D}$ は, これらの中 間的性格のグループである。

一方，コミュニティが掲げる活動の目標は，6つの事例で 脚注 5) Good Manufacturing Practiceの略であり，製造管理およ び品質管理の基準を指す。 
共通している。第一に経済的・精神的な自立, 第二に健康, 安定した生活, メンバーの幸せ, 第三に出稼ぎの必要をなく すために地域に仕事をつくり，若者が戻ってくる状態にする ことである。6つの事例は, 強弱はあるものの, 「足るを知る」 経済理念の実践を目指す活動であると言える。例えば，事 例 $\mathrm{E}$ は優れたリーダーの強力な統率力によるグループである が，リーダー自らがラーニングセンターとなり，地域住民に技 術や知識，考え方を伝授し地域の能力を底上げすることに 尽力している。また, 事例 $\mathrm{F}$ はリーダーの私企業的な傾向 が強いが, 地元の小学校への寄付など, 得られた利益を地 域に還元している。

\section{4. インタビュー調査結果 : パラボラドーム導入にともなう変化} 本章では，3.1節の（1）から（8）の質問項目について， イ ンタビュー調査から得られた結果を述べる。まず, 4.1 節, 4.2

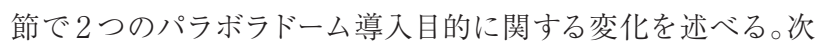
に, 4.3 節以降でインプット, ビジネスプロセス, アウトプット, アウトカム，ゴールに関する変化を述べるとともに, Fig. 4 に変化があった事例と変化の内容をまとめた結果を示す。

\section{1 化石燃料使用量の変化}

パラボラドーム導入前に LPG 乾燥機を使用していた事例 $\mathrm{E}$ では, 化石燃料使用量が減少した。以前の乾燥機では $60^{\circ} \mathrm{C}$ で1日 8 時間× 3 日間の乾燥を行っており, ドライトマト $1 \mathrm{~kg}$ あたり 3 Bahtのガス代・電気代がかかっていた。パラボラ ドームでは LPG も電力も用いていないため, 年間で 1.5 万 〜3 万 Bahtのコストが削減された。

事例 C・D は, 導入前のキャビネット型太陽熱乾燥機では 化石燃料を使用していない。必要以上に乾燥時間が長くな るとドライバナナの品質が低下するため, 雨天が長期間続く 場合は例外的にパラボラドーム内の LPG バーナーを用いるこ ともあるが, LPGの使用によるコスト増加を避けるため, ほ ぼ太陽熱のみで乾燥を行っている。導入前に天日干しを行っ ていた事例 $\mathrm{A} \cdot \mathrm{B} \cdot \mathrm{F}$ は, 現在でも乾燥に $\mathrm{LPG}$ を用いること はない。よって, 化石燃料の使用量に変化はなかった。

\section{2 衛生面における品質の変化}

LPG 乾燥機を使用していた事例 $\mathrm{E}$ を除く全てのグループ に扔いて, 衛生面での品質が向上した。特に, 食品を生産

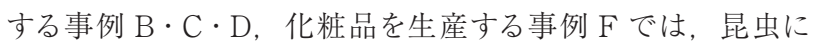
よる被害や埃の混入がなくなったことで製品の清潔度が高ま

り，付加価值が格段に向上する効果が得られている。

\section{3 メンバーに関する変化}

パラボラドーム導入が個人の意識や能力にもたらした変化 として，5つのグループから労働意欲 (モチベーション) の 向上があげられた。

事例 A では，導入前は天日干しであったため，雨が降る 度に乾燥中の莘を全て片づけなければならなかった。しか し, パラボラドームにより, その労力が必要なくなり, また, 常に雨を気にしなければならない心理的負担がなくなったた め, より一層やる気が出たと回答した。事例 B でも同様に, パラボラドーム導入によって雨や風を気にする必要がなくな り, 肉体的・精神的苦労が低減され楽になったため, より一 層やる気が出たと回答した。事例 C・D ではキャビネット型 太陽熱乾燥機を用いていたが, 天日干しと同様に雨の場合 は全て片づけなければならない。雨により乾燥中の製品が 全滅してしまうこともあるため, 乾燥期間中はどこにも出かけ られず，常に雨の心配をしてなければならなかった。その苦 労がなくなったため, パラボラドーム導入はメンバーのやる 気に非常に強い影響を与えている。天日干しを行っていた事 例 $\mathrm{F} も$ 同様に, パラボラドームによって雨天の日も夜間も化 粧品を片づける必要がなくなった。それにより労働負荷が軽 くなり心に余裕ができたため, メンバーのやる気が向上した

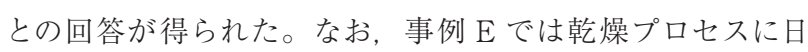
雇いの労働力を用いているため, メンバーの意識や能力の変 化に対する言及はなかった。

\section{4 組織に関する変化}

事例 D において, パラボラドーム導入によりメンバー同士 の関係性にプラスの変化があった。事例 Dでは, 30 人のメ

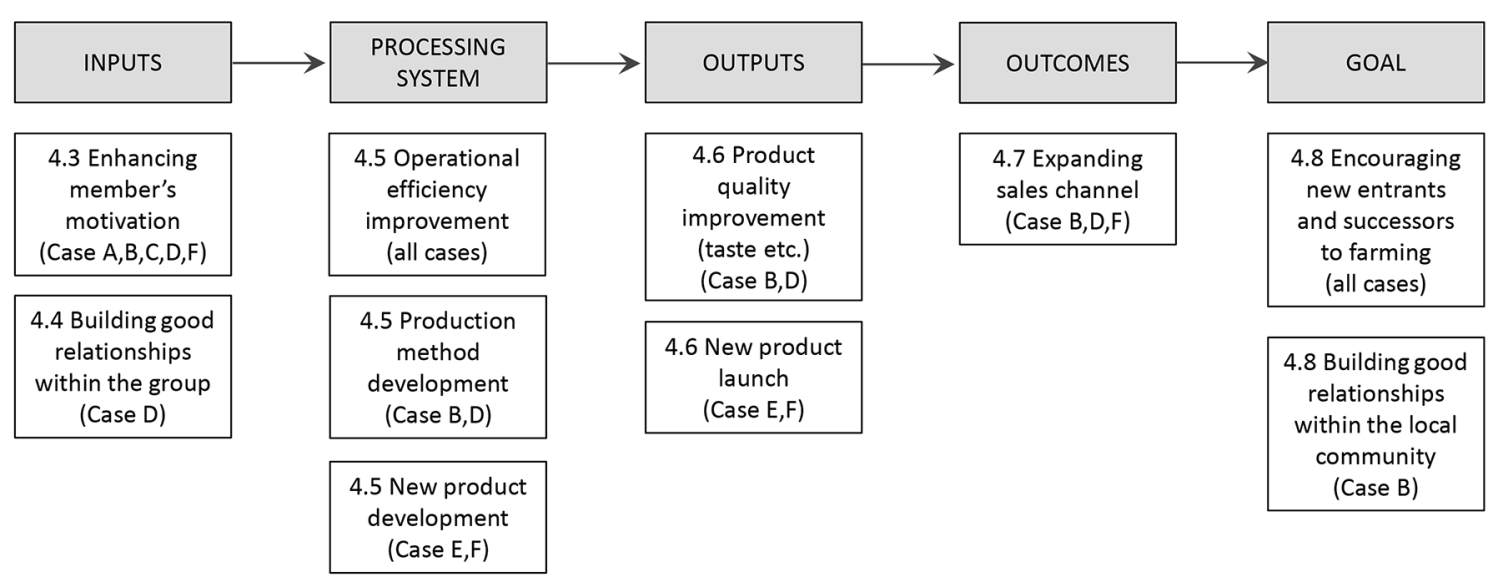

Fig. 4 Summary of changes after installation of solar drying systems 
ンバー中 15 人がパラボラドームを所有している。パラボラドー ムを所有していないメンバーが乾燥を行う際は, 他のメンバー が所有するパラボラドームを使用している。導入前は, メン バーは全ての製造プロセスを各々の家で行っていたため, メ ンバー同士が接触する機会があまりなかった。パラボラドー ムを共同で使用することにより，接触機会が増加し，コミュ ニケーションを取る頻度が高まった。また，スケジュール管 理のための調整や合意形成が必要になり，協力して仕事を 行う機会が増えた。それによりメンバー同士の関係性が深ま り，一層の一体感が生まれた。なお，他の5つのグループで は，組織に関する変化についての言及はなかった。

\section{5 経営資源の変換過程に関する変化}

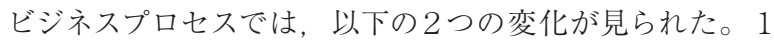
つはパラボラドームの特性がもたらす変化，もう1つは導入 をきっかけに起きた自発的学習がもたらす変化である。

前者では，全グループに共通して乾燥日数の短縮があげ られた。例えば，事例 A では，以前は染色前の乾燥に1 2 週間かかっていたが，導入後は 4 日間に短縮された。同

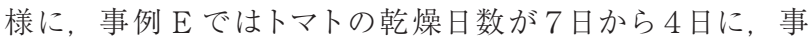
例 $\mathrm{F}$ では化粧品の乾燥日数が 4 日から 2 日に短縮された。ま た，事例 E からは作業効率の改善が変化としてあげられた。 LPG 乾燥機では 1 回に乾燥できる量は $300 \mathrm{~kg}$ だったが, パ ラボラドームでは 1 回に $1,000 \mathrm{~kg}$ のトマトを乾燥できるように なった。また，LPG 乾燥機では内部のトレーの上下を入れ替 える作業が必要だったが, 導入後はその作業が必要なくなっ た。

後者の変化は，事例 $\mathrm{B}, \mathrm{D}, \mathrm{E}, \mathrm{F}$ で見られた。事例 $\mathrm{B}$ では，パラボラドーム導入を契機に，以前は油で揚げる前に のみ行っていた乾燥を，油で揚げた後も行うように生産方法 を変更した。事例 D では，導入により乾燥温度等が変わっ たため，新たな乾燥方法を開発した。事例 $\mathrm{E}, \mathrm{F}$ では，導 入に伴い, より高付加価值な製品の生産が可能になったこと をきっかけに新製品の開発に取り組んだ。

\section{6 生産物に関する変化}

生産物に関する変化も, 前節と同様に, パラボラドームの 特性がもたらす変化と, 自発的学習の結果としての変化の 2 つに分類される。前者では, 事例 $\mathrm{C} \cdot \mathrm{D}$ において, パラボラドー 厶の方が以前よりも外観や食味の面で品質が安定するという 効果が得られている。また, 事例 $\mathrm{E} に$ にいて, ドライトマト の水分含有率が LPG 乾燥機使用時の $50 \%$ から $14 \%$ にまで 低下するという効果が得られた。

後者では, 事例 Bにおいて, 生産方法を改良した結果, 以前よりも食味や消費期限の点で製品品質が向上した。事 例 D でも同様に，食味，外観，食感の点で製品品質が向上 した。事例 Eでは, チリ味, 梅味, ライム蜂蜜味などの新 商品が開発された。事例 $\mathrm{F}$ では，伝統的なルースパウダー よりも高付加価值なフェイスパウダーの開発に成功している。 なお，事例 A は，乾燥方法が変わったことで莘製品に変化
があるかどうかは不明との回答であった。

\section{7 事業の成果に関する変化}

各グループとも，導入により製品品質が向上しても販売単 価を上げることは行っていない。しかし，事例 B·D·Fでは， 消費者の評価が高まり販路が拡大した。

\section{8 活動の最終的な目標に関する变化}

コミュニテイ活動の最終的な目標に関する変化としては, 以下の 2 点があげられた。1点目は, 次世代の後継者の確 保である。夕イにおいても, 後継者問題は深刻である。昔と 同じ重労働では若者は農業を継がない。そのため，身体的・ 精神的な負荷を低減させ，農業に対する心理的なハードルを 下げる必要がある。軽労化を可能にするパラボラドームの導 入は「未来につながる」との意見が各グループのリーダーに 共通して聞かれた。

2 点目は，グループメンバー以外の地域住民との関係性の 強化である。事例 B では，パラボラドームを使用していない 時に，同じタンボンに住むグループメンバー以外の住民にも パラボラドームを開放している。タンボンの住民は, 唐辛子 やナッツなど, 自らが栽培する様々な作物の乾燥にパラボラ ドームを利用している。つまり, 事例 D では, グループメン バー間での共有がなされていたが (4.4 節参照), 事例 B で はメンバー以外の地域住民との共有がなされている。パラボ ラドームの共同利用を通して, 住民同士のコミュニケーショ ン頻度が高まり，また，利用の順番を決める調整や合意形 成が行われるようになった。これにより，住民同士の関係性 が良くなり，地域内でのつながりが深まった。

\section{5. 分析と考察：直接効果と間接的効果}

事例分析より，パラボラドームの導入目的に対する効果の 有無が確認されるとともに，3点のそれ以外の影響が見出さ れた。前者が導入に伴う直接効果であるのに対し，後者は 間接的効果と言える。

\section{1 直接効果}

1 点目の導入目的である化石燃料の削減は, 導入前に LPG 乾燥機を利用していた場合にその効果を得ることができ ることが示された。ただし，多くのコミュニティ・エンタープ ライズは高額な設備投資を行っておらず，また，機器整備の 支援を受けられるグループも多くないことから，LPG 乾燥機

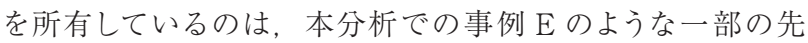
進的なグループに限られる。よって，コミュニティ・エンター プライズへの導入では，大きな化石燃料削減効果は期待でき ない可能性が高い。しかし，今後の機械化の進展を見据え れば，パラボラドームにより化石燃料消費を増加させること なく生産設備の高度化が図れることには価值がある。なお, 化石燃料が削減されるのはパラボラドーム使用時であり，パ イプや被覆資材の製造，輸送，建設にともなう化石燃料は 考慮していない点に留意する必要がある。 
2点目の目的である衛生面での品質向上は, 導入前に天日 干し，あるいは簡易的な太陽熱乾燥機を用いていた場合に 効果が得られることが示された。本分析では事例 B・C・D・ F がこれにあたる。近年, コミュニテイ経済活動に対しても, 食品等を扱う場合の衛生基準が厳格化されている。よって, 生産環境の衛生状態が改善され, 衛生度の高い製品の生産 を可能にする技術はコミュニテイ活動の維持・発展において 大きな意味を持つ。

\section{2 間接的効果}

\subsection{1 コミュニティの主体性向上への貢献}

第一の価值は, モチベーションの向上である。パラボラドー ムの導入により, 天候に左右される身体的・精神的苦労から 解放された。その軽労化の効果は極めて大きく, そこからモ チベーションの向上が引き起こされることが明らかになった。 この効果は, 生産にメンバー以外の労働者を雇用している事 例 $\mathrm{E}$ を除く5つの事例全てで確認された。モチベーションの 向上は, 活動での主体的な取組みにつながる非常に重要な 要素である。メンバーの主体性が低いグループは, メンバー の活動への参加率が低く, リーダーへの依存度が高くなり, その結果, 活動が上手く行かなくなるケースが多い。また, 主体的に考え行動しなければ, 活動の目標である精神的自 立を達成することも不可能である。そのため, 夕イ政府はメ ンバーによる主体的取組みの重要性を強調している。

しかし，政府が現在コミュニテイ活動に対して行っている 支援策は, 技術研修やマーケテイング·会計研修, 成功グルー プの活動の視察などテクニカルな面での支援策のみであり, 主体性を高めることを目的とした施策は行われていない。言 い換えれば，主体性獲得に向けてメンバーの意識改革を醸 成する優れたリーダーの存在といった偶発性に依存している のである。それゆえに, パラボラドームの導入によるモチベー ションの向上は, これまで注目されていなかった新たな視点 からのコミュニティ活動支援策となる可能性がある。

\subsection{2 コミュニティの学習誘発と能力向上への貢献}

第二の価值は，学習の誘発である。調査対象とした6つ の事例のうち，4つの事例でパラボラドーム導入により乾燥 方法が変わったことをきっかけに学習が行われた。事例 B では, 他のキノコクラッカー製品を研究し, 食味を改善する 新たな生産方法を見出した。事例 D でも他の製品を参考に, ドライバナナの食味等がより向上する乾燥方法を追求した。 事例 $\mathrm{E}$ では, ドライトマト市場の動向把握のための情報収 集や知識習得に注力し, 多様な製品の試作を行った。事例 $\mathrm{F}$ では, 消費者ニーズの把握に努め, より現代的な化粧品 を作るために工夫を重ねた。その結果, 製品の品質向上や 多様化，新製品の開発が実現された。

農産品およびその加工品は, 類似した製品が数多く存在 するため競争が激しく，事業継続のためには学習を続けて 差別化を図ることが求められる。本分析の事例でも，パラ ボラドームを導入しても学習が行われず品質向上につながら なかった事例 Cでは，商品の差別化が図れずに経営に苦慮
している。政府は「発展プロセスは学習プロセスである」と し，能力向上のための様々な研修の実施に力を注いでいる。 しかし，自発的な学習を促すという観点からの支援は行われ ていない。

グループでの経済活動を通して農民の能力を全体的に底 上げすることが，コミュニティ・エンタープライズ政策の主目 的である。しかし，支援策の恩恵は，ともすれば能力の高 い一部のグループに偏りがちである。また，全てのグループ を手助けできる程に農業普及員の数は多くない。そのため, どのようなグループであっても自発的な学習が行われる仕組 みを構築することが望まれる。パラボラドームによる乾燥方 法の変化という機会は, 自然に学習を誘発する有効な手段 となる可能性を持つ。さらに, 本分析の結果より, 導入と同 時に市場や消費者に関する情報の提供や先進事例の視察な どの支援を行うことが，より学習を後押しすることが示唆さ れた。

\subsection{3 地域社会の持続性向上への貢献}

第三の効果は, 地域社会の基盤を強化し, 地域の持続性 を高めることである。第三の効果は, 次の 2 つの価值から成 る。1つ目はコミュニティならびに地域の人間関係の強化と いう価值, 2 つ目は後継者の確保という長期的視点からの 価值である。

1つ目の価值は，パラボラドームの共有化によりもたらさ れる。事例 Dより, パラボラドームの共同利用により, グルー プ内の人間関係が改善される可能性が見出された。グルー プ運営に関する支援策としては, 透明性の確保の指導など が行われているが, メンバーの関係性を改善するための施策 の必要性には関心が払われておらず, グループが元々持つ関 係性に運営の成否が委ねられている。しかし, 人間関係に 問題を抱えるケースは多く, メンバー間の信頼関係をより強 化するための施策は必要である。事例 D は, 事例 A・B の ようにもともとメンバーの結束が強いグループではなかった。 こうしたグループにとって, 協働の場が作られることは関係 性強化に有効であると考えられる。

さらに, 事例 B より, グループと地域住民とでパラボラドー ムを共有することにより地域の関係性が強まり,つながりが 深まる可能性が見出された。従来, タイの農村ではコミュニ ティによる伝統的な共同作業が行われ, 互助システムが機 能し, 地域の基盤が形成されていた。しかし, 効率的な農 業生産の追求が日雇い労働による農作業を進展させ，また， 農業所得の相対的な低下により多くの農家が出稼ぎ労働者と してバンコクへ流出したことからコミュニティの弱体化が進ん だ。パラボラドームの共有は, 現代版の共同作業としてコミュ ニティの基盤強化に貢献し, 組織運営の持続性のみならず, 地域の持続性にもつながる可能性を持つ。

$2 つ$ 目の価值は, パラボラドームによる軽労化という効果 によりもたらされる。タイにおいても若年層にとっての農業は, 「大変, 疲れる, やりたくない」というイメージであると複数 の DOAE スタッフやグループリーダーが発言している。後継 者不足, 世代交代の停滞は, 夕イ農業全体の課題である ${ }^{17)}$ 
そのため, 技術導入による作業の軽労化が強く求められて いる。若者が地域に戻ることは，コミュニテイ経済活動の最 終的な目標の一つである。地域の持続性への貢献可能性は, 極めて重要な価值であると言える。

\section{6. おわりに}

本研究では, 太陽熱乾燥システムの導入がタイのコミュニ ティ経済活動の維持・発展に貢献するかという問いに対し, 人的資本・組織資本, 生産プロセス, 活動の目標への影響 に着目して分析を行った。事例分析より，パラボラドーム導 入がもたらす間接的効果, すなわち, 新たな価值として以下 の3点が見出された。1つ目は, 軽労化という労働環境の改 善がメンバーの主体性を引き出す可能性である。2つ目は, 導入によって乾燥方法が変革されることをトリガーとして, 能 力向上のための学習を誘発する可能性である。3つ目は, コ ミュニティや地域のつながりを深めること, そして後継者を 確保することである。これらの価值に加えて，導入目的とし て期待されている衛生面での付加価值向上という主効果も 確実に生み出されることが明らかになった。

重要な点は, これら4つの価值が製品製造時の化石燃料 の消費を増加させることなく得られる点である。これらの価 值は，他の技術でももたらし得るものである。しかし，化石 燃料の使用を伴わずにその価值を実現するところに，再生 可能エネルギー利用技術としてのパラボラドームの意義があ る。本分析の結果は, パラボラドームが, 気候変動の緩和と いう地球環境の持続性に寄与するだけでなく，途上国にお ける農村コミュニティの持続的な発展に寄与する可能性を示 唆している。

なお，本研究で用いた手法は，他の生産用途の再生可能 エネルギー技術に対しても適用可能であると考えられるが, 本稿の分析は定性的な評価にとどまっている。今後は，導 入前後での化石燃料消費量の変化などを, 可能な限り定量 的に評価する必要がある。ただし，能力向上や関係性強化 といった導入効果を定量化することは難しい。さらに，アウ トプットとして把握された販路拡大等の成果から, パラボラ ドーム導入効果以外の要因の影響を定量的に除外すること は容易ではない。こうした分析方法の課題については，今後 も検討を重ねる必要がある。

\section{謝 辞}

本研究は, 住友財団環境研究助成 (助成番号 : 164042) の支援を受けて実施されました。

\section{文 献: References}

1) Mondal, M. A. H.; Kamp, L. M.; Pachova, N. I., Energy Policy, 38, 4626-4634 (2010)

2) Terrapon-Pfaffn J.; Dienst C.; König J.; Ortiz W., Renew Sust Energ Rev, 40, 1-10 (2014)

3) Reddy V. R.; Uitto J. I.; Frans D. R.; Matin N., Energy Policy, 34, 4069-4080 (2006)
4) Organisation for Economic Co-operation and Development, Linking renewable energy to rural development, OECD, Paris, France, (2012)

5) Brummer, V., Renew Sustain Energy Rev, 94, 187-196 (2018)

6) Sastresa, E. L.; Usón, A. A.; Bribián, I. Z.; Scarpellini, S., Renew Sustain Energy Rev., 14, 679-690 (2010)

7) Slattery, M. C.; Lantz, E.; Johnson, B. L., Energy Policy, 39, $7930-7940$ (2011)

8) Waldenström, C.: Ferguson, R.; Sundberg, C.; Tidåker, P.; Westholm, E.; Åkersko, A., Soc Nat Resour, 29, 1467-1482 (2016)

9) del Rio, P.; Burguillo, M., Renew Sustain Energy Rev, 13, 1314-1325 (2009)

10) Terrapon-Pfaff, J.; Gröne, M. C.; Dienst, C.; Ortiz, W., Renew Sustain Energy Rev, 96, 198-209 (2018)

11) Berka, A. L.; Creamer, E., Renew Sustain Energy Rev, 82, 3400-3419 (2018)

12) Sharma, A.; Chen, C. R.; Lan, N. V., Renew Sustain Energy Rev, 13, 1185-1210 (2009)

13) Fudholi, A.; Sopian, K.; Ruslan, M. H.; Alghoul, M. A.; Sulaiman, M. Y., Renew Sustain Energy Rev, 14, 1-30 (2010)

14) VijayaVenkataRaman, S.; Iniyan, S.; Goic, R., Renew Sustain Energy Rev, 16, 2652-2670 (2012)

15) Department of Alternative Energy Development and Efficiency, http://e-lib.dede.go.th/mm-data/ BibA9434_2018.pdf (Last access: July 5, 2020)

16) Department of Alternative Energy Development and Efficiency, http://www.eppo.go.th/images/POLICY/ ENG/AEDP2015ENG.pdf (Last access: July 5, 2020)

17) Ministry of Agriculture and Cooperatives, https://qsds. go.th/newopdc/wp-content/uploads/sites/7/2020/01/ Cooperatives3.pdf (Last access: July 5, 2020)

18) Ministry of Foreign Affairs, http://www.mfa.go.th/ dvifa/contents/files/articles-20170626-142701-203959.pdf (Last access: July 5, 2020)

19) Charnnarongkul, J., APEC-Agricultural Technical Cooperation Working Group Workshop, Oct. 28-30, 2009, Bali, Indonesia

20) Sakolnakorn, T. P. N.; Naipinit, A., Asian Social Science, 9 , 166-173 (2013)

21) Purateera, T.; Khmanarong, S.; Phanarata, A.; Khamanarong, K., International Business \& Economic Research Journal, 8, 41-46 (2009)

22) Somswasdi, C.; Thongsukhowong, A.; Nakapaksin, S., Asian Social Science, 11, 91-96 (2015)

23) Forson, F. K.; Nazha, M. A. A.; Rajakaruna, A. F. O., Renew. Energy, 32, 2306-2319 (2007)

24) Kaewkiew, J.; Nabnean, S.; Janjai, S., Proc Eng, 32, 433$439(2012)$ 
25) Fudholi, A.; Sopian, K.; Alghoul, M. A.; Ruslan, M. H.; Othman, M. Y., Renew. Energy, 78, 561-565 (2015)

26) Sekyere, C. K. K.; Forson, F. K.; Adam, F. W., Renew. Energy, 92, 532-542 (2016)

27) Essalhi, H.; Benchrifa, M.; Tadili, R.; Bargach, M. N., Innov Food Sci Emerg Technol, 49, 58-64 (2018)

28) Sreekumar, A.; Manikantan, P. E.; Vijayakumar, K. P., Energy Convers Manage, 49, 1388-1395 (2008)

29) Nabnean, S.; Janjai, S.; Thepa, S.; Sudaprasert, K.; Songprakorp, R.; Bala, B. K., Renew. Energy, 94, 147-156 (2016)

30) Janjai, S.; Srisitipokakun, N.; Bala, B. K., Energy, 33, 91103 (2008)

31) Elkhadraoui, A.; Kooli, S.; Hamdi, I.; Farhat, A., Renew. Energy, 77, 1-8 (2015)

32) Hossain, M. A.; Bala, B. K., Solar Energy, 81, 85-92 (2007)

33) Janjai, S.; Lamlert, N.; Intawee, P.; Mahayothee, B.; Bala, B. K.; Nagle, M.; Muller, J. E., Sol. Energy, 83, 1550-1565 (2009)
34) Janjai S. A., Int J Energy Environ, 3, 383-398 (2012)

35) Kumar, A.; Kandpal, T. C., Solar Energy, 78, 321-329 (2005)

36) Singh, S.; Kumar, S., Energy, 51, 27-36 (2013)

37) Tripathy, P. P., J Food Sci Technol, 52, 1383-93 (2015)

38) Ayyapan, S., Energy Environ, 29, 1482-1494 (2018)

39) Ruengdet, K.; Wongsurawat, W., Journal of Agricultural Education and Extension, 16, 385-397 (2010)

40) Sutthisakorn, U., International Journal of Business and Management Studies, 2, 41-47 (2013)

41) Laiprakobsup, T., Asian Geographer, 35, 53-84 (2018)

42) Nuansoi, W.; Suntiniyompukdee, A.; Bunnoon, P., Proceedings of ISER 107th International Conf., 10 -11 Feb. 2018, Pattaya, Thailand

43) Yenpiam K., Journal of Human Capital Development, 6, 2757 (2013)

44) Brown, M. G., Keeping Score: Using the Right Metrics to Drive World Class Performance, Quality Resources, New York, NY, (1996) 